\title{
EFFICACY OF SOME BIOAGENTS AND NEMASTOP COMPOUND IN CONTROLLING ROOT KNOT DISEASE ON PEANUT. \\ Howida A. Metwaly ${ }^{1}$ and Hanaa S. Zawam ${ }^{2}$ \\ 1- Central Laboratory of Organic Agriculture, Agricultural Research Center,Giza, Egypt. \\ 2- Nematode Research Department,Plant Pathology Research Institute, Agricultural Research Center, Giza, Egypt.
}

\begin{abstract}
Biological control of plant diseases especially root knot nematode has been handled in many scientific papers. Bacillus subtilis, Trichoderma harzianum (T1), $T$. viride (T2), mixture of both (T1andT2) in addition to the commercial product Nemastop were used under field conditions to control root knot nematode, Meloidogyne javanica Chitwood on peanut plants which was the most frequent extracted from soil and roots

The efficacy of the treatments at different concentrations was also assayed under laboratory conditions as percentage of juvenile mortality and inhibition of egg hatching. All treatments revealed good effect in controlling root-knot at the highest concentrations, Nemastop was the most effective at(1:10), whereas, B. subtilis was the lowest one. Results obtained from field experiments were in harmony with those obtained from laboratory compared with control. Efficacy of the treatment also positively correlated with number of application time. The plot treated with any one of the bioagents tested three times achieved highest effect in controlling root knot nematode and increased peanut yield. Under field condition mixture of Trichoderma isolates was the most effective followed by Nemastop.
\end{abstract}

Keywords: Biological agents, Root-knot nematode, Meloidogyne javanica, Peanut, Bacillus subtilis, Trichoderma harzianum, T. viride.

\section{INTRODUCTION}

Peanut (Arachis hypogaea L.), is very important annual herb legume crop of tropical and subtropical areas of the world. The importance of peanut as a food and oil crop and as a cash source in the semi-arid tropics is well known. Peanuts are rich in energy and contain health benefit nutrients ,minerals ,antioxidants and vitamins that are essential for optimum health (Umesh 2009). The production of peanut is negatively affected by soil borne fungi and nematodes. Root-knot nematodes (Meloidogyne spp.),are considered the most important plant parasitic nematodes attacking more than 2000 plant species(Jung and Wyss 1999)..Reduction in yield of peanut was recorded due to more than 55 pathogens including fungi, bacteria, viruses, mycoplasma, nematodes and parasitic flowering plants (Podile and Kishore 2002). Plant parasitic nematodes cause significant damage to agriculture throughout the world. The damage caused by the root-knot nematodes are much higher in tropical and sub-tropical countries compare with cold ones (Sasser and Freckman 1987). The presence of root-knot nematodes in the roots induces galls that restrict nutrient, water uptake and peanut growth, while also facilitating fungal infections . Root-knot nematodes are the most 
significant nematode pest of Egyptian peanut and can cause up to $60 \%$ yield loss (Sharma and McDonald 1990).

In recent years, the awareness of the fungicides and nematicides hazards to human and environment has directed the attention towards soilborne antagonists and natural products to control nematodes in replacing of chemicals. Biological control is gaining increase role throughout the world for nematode suppression .The genus, Trichoderma is common saprophytic filamentous imperfect fungus and considered as the most common fungi in the rhizosphere and found in almost all soil type. Sharon et al., 2001 reported that $T$. harzianum was antagonistic organism to root knot pathogen $M$. javanica in soil. Other Trichoderma species and isolates have also exhibited significant biocontrol activity against $M$. javanica in growth chamber experiments.

Biological control is gaining increasing role throughout the world for soil pathogens and nematodes suppression. Mixing antagonists with each others may be lead to antagonistic effect consequently decrease efficacy of treatment or lead to synergistic effect and increase the efficacy (Robinson et al., 2009).

Bacillus subtilis is reported as a biocontrol agent against root-knot nematodes. (Khan et al.,2002,Huang et al., 2005 and Huang et al., 2009).Several reports clarified that the basic mechanisms of $B$. subtilis included production of extracellular antibiotics metabolites or enzymes (e.g. proteases, chitinases and glucanases), stimulation of host defenses, incensement of plant growth, induced systemic resistance in plants, suppression of the plant diseases and secreting volatile nematicidal substances (Abd- El- Moneim,2005, Ji et al.,2006,Kloepper and Ryu 2006 and Lahlali et al.,2013).

The present study is conducted to control the root knot nematode on peanut plants, different biocontrol agents T.harzianum, T. viride, mixture of both and $B$. subtilis as well as Nemastop are used to improve protection effect against this disease and to increase the peanut yield. Also, to determine the effect of these biological treatments compared with control under laboratory as well as field conditions.

\section{MATERIALS AND METHODS}

Bioagents and biocide:

Different biocontrol agents, B. subtilis, T. harzianum (T1), T. viride (T2), mixture of both T1and T2 and a commercial biocide, Nemastop were kindly obtained from central lab of Organic Agricultural Research Center, Giza, Egypt. B. subtilis was grown on nutrient glucose broth (NGB) suggested by Dowson (1957) T. harzianum (T1), T. viride (T2) were grown in liquid gliotoxin fermentation medium (GFM) (Brian and Hemming 1945).The bioagents were allowed to grow under complete darkness for nine days just to stimulate toxin production at $28^{\circ} \mathrm{C}$ (Abd-El-Moity and Shatla 1981). Different bioagents were formulated as suspension using method developed by Abd-El-Moity(1985). Prepared suspension was adjusted to contain $30 \mathrm{x}$ $10^{6} \mathrm{cfu} / \mathrm{ml}$ and mixture of them was added as (1:1).Nemastop was used as 
commercial biocide to compare its effect with other bioagents against root knot nematode on peanut. Peanut shoot weight, shoot length, root weight, root length and yield were determined.

\section{Extraction and classification of Nematodes:-}

Nematode infestation was verified by analysis of soil samples by a laboratory specialist. Different kinds of nematode infested the soil samples associated with rhizosphere of roots and root galls which showed identical galls root knot symptoms from peanut plants collected through the experimental duration in two seasons in El-Bustan Research Station, Nubaria-Behira Governorate, Egypt. An aliquot of $250 \mathrm{~cm}^{3}$ from each soil sample was processed for nematode extraction by sieving and modified Bearman technique (Goodey, 1957). After 48 hours the extracted nematodes were counted using $1 \mathrm{ml}$ Hawksly counting slide under a stereo microscope and classified according to (Mai and Lyon 1975 and Siddiqi 1986) females of root knot nematode were excised from large galls on the roots of peanut plants and individually macerated and accomplished with automated apparatus( Phast System Pharmacia, Uppsala,Sweden) to have esterase phenotype (Tomaszewski,et al.,1994)

Effect of biocontrol agents on M. javanica under laboratory and field conditions I- Laboratory experiment:-

To study the efficacy of biocontrol agents on $M$. javanica under laboratory conditions, one $\mathrm{ml}$ of each biocontrol agents (B.subtilus , $T$. harzianum (T1), T. viride (T2) and mixture of (T1and T2) were containing (30 $\left.x 10^{6}\right) \mathrm{cfu} / \mathrm{ml}$ and Nemastop were added to nematode suspension at different concentrations $(1: 10,1: 25$ and1:50) in glass vials for each of them. Each of biocontrol agent suspension was added to five handpicked egg-masses and to 500 active nematode juveniles to detect their effect on hatching and juveniles mortality of $M$. javanica. The same number of egg-masses and juveniles received distilled water and served as control. Each treatment was applied in three replicates. The percentage of inhibition in egg hatching was recorded after 3 days and the percentage of Juveniles mortality was recorded after 48 hours under a stereoscopic microscope.

\section{II- Field experiments:-}

Field experiment was carried out in naturally heavy infested field with M. javanica at El-Bustan Research Station, Nubaria-Behira Governorate, Egypt in April 2012 / 2013 growing seasons. A randomized complete block design with 5 replications was used in each season. A field experiment consisted of plots $(7 \times 6 \mathrm{~m})$; each comprised of 10 rows $20 \mathrm{~cm}$ distance and 30 holes/row at which each treatment was conducted with five plots as replicates as well as check treatment. Gliotoxin fermentation medium (GFM) used to grow the bioagents. B. subtilis, $T$. harzianum (T1), T. viride (T2), mixture (T1andT2) and Nemastop were used as seed coating before sowing and sprinkled as a liquid at rate of $10 \mathrm{~L} / \mathrm{fed}$. after 15 days of sowing(two times applications) and after month of sowing (three times applications).

Plants only treated with water act as control treatment. Peanut seeds Giza 6 obtained from Field Crop Research Institute, Agricultural Research 
Centre, Giza. All treatments received the same agricultural treatment such as amount of water, number of seeds /plot and amount of fertilizers.

Effect of applications time using biocontrol agents against ( $M$. javanica) in peanut.

Different bioagents were used as one, two and three applications with interval 15 days between applications. Biocontrol agents were used in liquid form and the first treatment was applied as seed coating in the suspension for 20 minutes, where the second and third treatments were applied as soil drench, at five liters of each bioagent / plot. Treated plants were examined at the end of seasons. The roots were then washed to get rid of the adhering and particles to determine the number of root knot galls, juveniles in soil, eggs $/ 5 \mathrm{gm}$ roots, developmental stages in the roots. The number of nematode larvae (in $250 \mathrm{~cm}^{3}$ soil) and RF (Reproduction Factor) was determined according to Norton (1978).

Reproduction Factor $(\mathbf{R F})=$

No. Eggs + Developmental stages + Free Nematode in soil+ adult females

Developmental stages (DS) $=$ Initial Population

number of developed juveniles (third and fourth stages) embedded in the roots.

Efficiency of each treatment recorded according to the equation:-

$$
\text { Efficiency }=\underline{R F} \text { in control- RF in treatment } \times 100
$$

\section{RF in control}

At harvest some peanut parameters such as shoot length $(\mathrm{cm})$, shoot weight $(\mathrm{g})$, root length $(\mathrm{cm})$, root weight $(\mathrm{g})$ and yield of pods with kilogram per plot were determined and the efficacy of each bioagents were recorded as average of two seasons.

Statistical Analysis:-

Data obtained were subjected to statistical analysis of variance for completely randomized design (CRD) and randomized complete block design (RCBD) as outlined by Steel and Torrie (1980).

\section{RESULTS AND DISCUSSION}

\section{Nematode associated with peanut :-}

Data in Table (1) show the percentage frequency of the nematodes recovered species from El-Bustan Research Station, Nubaria-Behira governorate, Criconemella sp., $M$. javanica, Paratrichodorus minor, Pratylenchus sp. and Tylenchorhynchus sp. Lamberti (1981) stated that, plant parasitic nematodes account worldwide, for an average estimated by $10-20 \%$ yearly loss of agricultural peanut plants which multiplication and spread over thousands of feddans under best conditions. The most dominant root knot nematode was $M$. javanica. Root knot nematodes cause varying degrees of stunting, chlorosis depending on the initial population. (Taylor and Sasser, 1978) showed that more than $80 \%$ of the major Meloidogyne population belonged to $M$. javanica. Root-knot nematodes ( $M$. javanica) are among the most damaging nematodes in agriculture, causing an estimated US\$100 billion loss/year on peanut plants worldwide (Oka et al., 2000). M. javanica Chitwood 
and other root-knot nematodes cause galls in roots of many crops impeding normal uptake of water and nutrients.

Table (1): The percentage frequency of nematodes attacked peanut plants.

\begin{tabular}{|l|c|}
\hline Nematode genera & Frequency of occurrence \\
\hline Criconemella sp. & 1.37 \\
Meloidogyne javanica & 70.09 \\
Paratrichodorus minor & 3.50 \\
Pratylenchus sp. & 3.43 \\
Tylenchorhynchus sp. & 21.61 \\
\hline
\end{tabular}

Data in Table (1) indicate that, $M$. javanica was the most frequent species of overall the seasons of peanut with frequent percentages of $(70.09 \%)$ while, Criconemella sp. was the least frequent species with frequent percentages of $(1.37 \%)$.

Effect of different bioagents on the viability of $M$. javanica:-

The morphological change of $M$. javanica juveniles was examined using an inverted microscope during 7 days of incubation at $27^{\circ} \mathrm{C}$. Deforming of juveniles was showed in Figures (1:5), for treatments and the figure (6) for untreated control. Some juveniles appeared thin with destruction in some parts, but no deforming was observed in the control. Observations through the inverted microscope demonstrated that the microorganisms were widely attached the juveniles of $M$. javanica. The morphological changes of $M$. javanica juveniles agreed with the study of Westcott and Kluepfel (1993) who reported that chitinases produced by bacteria was potent in attacking the cuticle of M. javanica. Regarding to Trichoderma species (Ghisalberti 2002) reported that chitinolytic enzymes produced by these fungi are thought to be responsible for the degradation of cell walls; they also had ability to produce a wide range of secondary metabolites with diverse biological actions including mycoparasitism also through production of antibiotic substances. $T$. viride and $T$. harzianum destructed and lysis the juveniles body after seven days. The effect of Nemastop on root knot nematode might be due to alkyl cysteine sulphoxides which released a mixture of volatile alkyl thiols and sulphides, these volatile compounds override the inhibitory effect on parasitic nematode (Coley-Smith, 1976) ). Results of an antagonism test showed in (Table 2) had significant inhibition and mortality as affected by treatments of $B$. subtilis, $T$. harzianum, T. viride, mixture of them (T1,T2 ) and Nemastop compound . 
Howida A. Metwaly and Hanaa S. Zawam

Fig. (2): Interaction between bioagents and juvenile of pathogenic nematode 
These bioagents had various degrees of effectiveness toward the nematode juveniles. Moreover, the percentage of mortality increased as increase of the concentration. Results also revealed there is positive correlation between different concentrations of treatments and efficacy of application. The obtained results might be due to the increase in the amount of the active component of bioagent. Nemastop was the most effective treatment of the three concentrations. The highest concentration (1:10) for all the tested treatments achieved the highest percentage of juvenile mortality and inhibition of eggs hatching. The inhibition in egg-hatching caused by all the used treatments ranged from $100 \%$ for both Nemastop and $T$. harzianum to $56 \%$ for $T$. viride. The lowest concentration (1:50) recorded the lowest percentage of egg hatching inhibition. Rahman Khan et al., (2005) mentioned that $B$. subtilis produce nematoxic metabolites that involved in the nematode suppression. The morphological change of M.javanica juveniles agreed with the study of Westcott and Kluepfel (1993) who reported that chitinases activity produced by PGPR were more potent in attacking eggs than the cuticle of M.incognita, this might have resulted from the direct damage caused by the bacterial chitinase.

Table (2): The inhibition and mortality of $M$. javanica as affected by biocontrol agents.

\begin{tabular}{|c|c|c|c|}
\hline Treatments & Concentrations & $\begin{array}{l}\text { Inhibition of egg } \\
\text { hatching } \%\end{array}$ & $\begin{array}{l}\text { Mortality of } \\
\text { juvenile \% }\end{array}$ \\
\hline \multirow{3}{*}{ B. subtilis } & $1 / 10$ & 59 & 75 \\
\hline & $1 / 25$ & 42 & 47 \\
\hline & $1 / 50$ & 19 & 30 \\
\hline \multirow{3}{*}{ T. harzainum (T1) } & $1 / 10$ & 100 & 96 \\
\hline & $1 / 25$ & 96 & 79 \\
\hline & $1 / 50$ & 79 & 68 \\
\hline \multirow{3}{*}{ T. viride (T2) } & $1 / 10$ & 56 & 87 \\
\hline & $1 / 25$ & 33 & 61 \\
\hline & $1 / 50$ & 20 & 36 \\
\hline \multirow{3}{*}{$\begin{array}{l}\text { Mixture of } \\
(\mathrm{T} 1+\mathrm{T} 2)\end{array}$} & $1 / 10$ & 94 & 95 \\
\hline & $1 / 25$ & 87 & 89 \\
\hline & $1 / 50$ & 73 & 78 \\
\hline \multirow{3}{*}{ Nemastop } & $1 / 10$ & 100 & 98 \\
\hline & $1 / 25$ & 95 & 95 \\
\hline & $1 / 50$ & 88 & 83 \\
\hline \multicolumn{2}{|l|}{ Control } & 0 & 0 \\
\hline \multirow{2}{*}{\multicolumn{2}{|c|}{$\begin{array}{l}\text { L.S.D. at } 5 \%(\text { TREATMENT }) \\
\text { L.S.D. at } 5 \%(\text { CONCN.) }\end{array}$}} & 2.625 & 1.977 \\
\hline & & 1.856 & 1.398 \\
\hline
\end{tabular}

Effect of applications time using biocontrol agents against ( $M$. javanica) in peanut.

To determine the suitable time for adding different antagonist to get the highest effect, different bioagents were added at three different times. These adding times were at planting time, fifteen days after planting and one month after planting. The early treatment showed the highest effect in plant protection and vice versa. Time of application was reflected on the yield and percentage of dry matter in treated plants. This is due to that early treatment, 
at planting time, allows propagules of used antagonist to spread out and surround newly developed roots causing protection against root knot nematode that may be found in court of infection. On the contrary, adding antagonist fifteen days and one month after planting this means that, the developed roots before this period, already attacked by pathogens which negatively affect plant growth and developing (Mannanov and Sattar 2009). That is why plants treated very early, at planting time, gave the highest yield and highest percentage in dry matter.

Data in Table (3)showed that, significant differences in the number of developmental stages and eggs $/ 5 \mathrm{~g}$ roots, Juveniles $/ 250 \mathrm{~cm}^{3}$ soil between peanut plants treated one time and those treated two or three times. In plants treated at three times, the percentage of nematodes was found to be less than those recorded after one or two times. This might be due to appearance of new roots on the treated plants free from the nematode infection. Obtained data also showed that, all antagonists significantly reduced the number of root galls, developmental stages and juveniles in soil. Mixture of Trichoderma spp. isolates showed good effect in controlling nematode. Mixing different isolates may increase the scope on mode of action consequently increase efficacy of the treatment this agree with Zhang and Zhang (2009) who showed that combination of isolated $T$. viride strain and $T$. harzianum reduced root galling and the number of new infection by nematode. $T$. harzianum parasitized eggs and larvae of nematode. The hyphae penetrate the eggs and larval cuticle by dissolving the chitin layer through enzymatic activity. They proliferate within the organism and produce toxic metabolites (Dos Santos et al., 1992). Thus, the enzymes produced by Trichoderma spp. such as chitinases, glucanases and proteases seem to play an important role in parasitism (Haran et al., 1996). Trichoderma has not only been proved to parasitize nematodes and inactivate pathogen enzymes but also help in tolerance by enhanced root development (Harman, 2000).Sharma and Pandey(2009) found that $T$. harzianum alone can reduce gall formation and improved plant growth. As known by Li et al. (2007) and (Kim et al., 1997) that $B$. subtilis produce antibiotics and antifungals that performed as biopesticide against nematode, as bacillomycin, iturin, surfactin, and agrocin. The reduction of nematode plant parasitic nematodes associated with $B$. subtilis may be attributed to diverse mechanisms which involve phytohormones production, mineral solubilisation, reduction of the activity of egg hatching factors, alteration of root exudates and inhibition of nematode penetration into the roots thereby interfering with host finding process and reducing galls 
J. Plant Prot. and Path., Mansoura Univ., Vol.6 (3), March, 2015

3- 
Data in Table (4) showed that positive correlation between numbers of application and plant growth improvement. All treatments either bioagent alone or in combination with each other as well as commercial biocide led to high significant effects on yield, shoots and roots (weight and length). Increase number of application to be two or three times led to significant increase in efficacy due to increase establishment of the antagonist which led to increase in yield of treated plants. This may be due to repeated treatment with bioagents which increase growth regulators and increase growing roots and also may increase plant nutrients uptake. Data also recorded that the mixture of Trichoderma isolates occupied the highest rank $(20.71 \mathrm{~kg} / \mathrm{plot})$ compared with control treatment at the third application. This may be explain as compatible relation between mixture of Trichoderma isolates, led to synergistic effect between them and increasing the uptake of macro and micro nutrients and improving all vegetative characters. This increase in yield may be due to that rhizosphere organisms produced greater amount of organic acids, such as tartaric, citric acid and lactic acid which may improve plant productivity and increase the root system growth.

Table(4):Effect of applications number using biocontrol agentsin improving agronomic characteristic on peanut plants.

\begin{tabular}{|c|c|c|c|c|c|c|c|c|c|c|c|}
\hline \multicolumn{2}{|c|}{$\begin{array}{c}\text { Yield } \\
\mathrm{kg} / \text { plot }\end{array}$} & \multicolumn{2}{|c|}{$\begin{array}{c}\text { Root } \\
\text { Length (cm.) }\end{array}$} & \multicolumn{2}{|c|}{$\begin{array}{c}\text { Roots } \\
\text { Weight(g.) }\end{array}$} & \multicolumn{2}{|c|}{\begin{tabular}{c|} 
Shoot \\
Length( $\mathrm{cm})$.
\end{tabular}} & \multicolumn{2}{|c|}{$\begin{array}{c}\text { Shoots } \\
\text { Weight(g.) }\end{array}$} & \multirow{2}{*}{$\begin{array}{c}\text { Applicatio } \\
\text { n time }\end{array}$} & \multirow[t]{2}{*}{ Treatments } \\
\hline 2013 & 2012 & 2013 & 2012 & 2013 & 2012 & 2013 & 2012 & 2013 & 2012 & & \\
\hline 11.2 & 9.28 & 22 & 25 & 39.03 & 25 & 29 & 27 & 73.7 & 32.98 & One time & \multirow{3}{*}{$\begin{array}{l}\text { Bacillus } \\
\text { subtilis }\end{array}$} \\
\hline 55.4 & 12.41 & 25 & 18 & 42.32 & 27 & 30 & 29 & 147.4 & 26.89 & Two time & \\
\hline 72 & 14.17 & 25 & 30 & 57.52 & 30 & 44 & 43.3 & 203.1 & 53.84 & Three time & \\
\hline 42.8 & 8.12 & 29 & 25 & 44.39 & 20 & 30 & 25 & 119.2 & 41.9 & One time & \multirow{3}{*}{$\begin{array}{l}\text { Trichoderma } \\
\text { harzianum } \\
\text { (T1) }\end{array}$} \\
\hline 53 & 9.47 & 30 & 27 & 66.05 & 20 & 38 & 26.8 & 140.3 & 42.87 & Two time & \\
\hline 55.34 & 11.64 & 30 & 20 & 71.47 & 30 & 39 & \begin{tabular}{|l|}
28.3 \\
\end{tabular} & 142.1 & 37.5 & Three time & \\
\hline 44.41 & 3.59 & 28 & 30 & 50.4 & 20 & 31 & 27 & 100.6 & 39.94 & One time & \multirow{3}{*}{$\begin{array}{l}\text { Trichoderma } \\
\text { viride (T2) }\end{array}$} \\
\hline 49.14 & 7.81 & 30 & 20 & 50.49 & 30 & 35 & 30 & 121.2 & 36.2 & Two time & \\
\hline 91.2 & 11.69 & 33 & 30 & 71.03 & \begin{tabular}{|l|}
36.7 \\
\end{tabular} & 39 & \begin{tabular}{|l|}
37.7 \\
\end{tabular} & 182.3 & 48.76 & Three time & \\
\hline 66.5 & 13.12 & 30 & 20 & 36.24 & 25 & 30 & 27.7 & 138.4 & 31.5 & One time & \multirow{3}{*}{$\begin{array}{l}\text { Mixture of } \\
-(T 1+T 2)\end{array}$} \\
\hline 67.8 & 13.57 & 35 & 36.7 & 41.88 & 30 & 34 & 32 & 148.6 & 62.04 & Two time & \\
\hline 79.13 & 20.71 & 40 & 25 & 59.07 & 35 & 44 & 45 & 162.3 & 47.28 & Three time & \\
\hline 70.15 & 12.61 & 30 & 35 & 43.82 & 30 & 31 & 22.7 & 140 & 55.31 & One time & \multirow{3}{*}{ Nemastop } \\
\hline 81.49 & 13.34 & 32 & 30 & 50.64 & 30 & 39 & 35 & 153.1 & 38.01 & Two time & \\
\hline 107.69 & 14.25 & 45 & 35 & 84.03 & 35 & 47 & 42 & 192.5 & 79.33 & Three time & \\
\hline 13.5 & 4.33 & 21 & 33.5 & 33.5 & 29 & 27.5 & 33.7 & 33.5 & 18 & Control & \\
\hline 1.171 & 0.45 & 1.077 & 0.88 & 0.689 & 0.90 & 1.131 & 0.747 & 1.774 & 2.92 & LSD at $5 \%$ & \\
\hline
\end{tabular}

\section{REFERENCES}

Abd-El-Moity, T. H. and M. N. Shatla (1981).Biological control of white rot disease of onion (Sclerotium cepivorum) by Trichoderma harzianum. Phytopathology, Z., 100: 29- 35.

Abd-El-Moity, T.H. (1985). Effect of single and mixture of Trichoderma harzianum isolates on controlling three different soil borne pathogens. Egypt. J. Microbial., Special Issue, 111-120. 
Abd-El-Moneim, Maisa ; L . (2005). Effect of some non-chemicals, seed and foliage applications on cotton damping off disease incidence and yield characteristics. Zagazig, J. Agric. Res., 32 (6):1829 - 1853.

Brian,P.W. and H.G.Hemming (1945). Gliotoxin as fungistatic metabolic product of Trichoderma viride .Ann.Appl. Biol., 32:214-220

Coley-Smith, J. R. (1976).Some interaction in soil between plants, sclerotiumforming fungi and other microorganisms. (In Biochemical aspects of Plant Parasite Relationships. Friend, J. and D. R. Threlfall (Eds,) . Academicpress London, New York, San Fracisco.pp.11-23.

Dos Santos, M.A.; S .Ferraz and J.J. Muchovej (1992). Evaluation of 20 species of fungi from Brazil for biocontrol of Meloidogyne incognita race-3. Nematropica 22: pp.183-192.

Dowson, W. J. (1957). Plant diseases due to bacteria second Ed., Cambridge the university Press, London, pp23.

Ghisalberti, E .L. (2002).Anti-infective agents produced by the hyphomycetes Genera Trichoderma and Gliocladium. Current Medicinal ChemistryAnti infective Agents ,1(4) 343-374.

Goodey, J.B. (1957). Laboratory methods for work with plant and soil nematodes. Tech. Bull. No. 2. Min. Agric. Fish Ed. London, 47 pp.

Haran, S.; H. Schickler and I.Chet (1996). Molecular mechanisms of lytic enzymes involved in the biocontrol activity of Trichoderma harzianum. Microbiol. 142: 2321-2331.

Harman GE (2000). The myths and dogmas of biocontrol: changes in perceptions derived from research on Trichoderma harzianum strains T-22. Plt Disease 84(4):377-393.

Huang, X. W.; N. H. Zhao and K. Q. Zhang. (2005). Extracellular enzymes serving as virulence factors in nematophagous fungi involved in infection of the host. Res. Microbiol. 115: 811-816.

Huang, Y., C. Xu, L. Ma, K. Zhang, C. Duan and M. Mo (2009).Characterisation of volatiles produced from Bacillus megatherium YFM3.25 and their nematicidal activity against Meloidogyne incognita. Euro. J. Plant Pathol. 26: 417-422.

Ji, P., H. Campbell; J. Kloepper; J. Jones; T. Suslow and M. Wilson (2006). Integrated biological control of bacterial speck and spot of tomato under field conditions using foliar biological control agents and plant growth promoting rhizobacteria. Biol. Cont. 36: 358-367.

Jung, C. and U. Wyss (1999). New approaches to control plant parasitic nematodes. Appl. Microbiol. Biotechnology. 51: 439-446.

Khan, M.R.; K. Kounsar and A. Hamid (2002). Effect of certain rhizobacteria and antagonistic fungi on root-knot nodulation and root-knot nematode disease of green gram. Nematologia Mediterranea, 30(1): 85-89.

Kim, H.S.; D.Y. Byung; H.L. Chang; H.S. Hyun; M.O. Hee; K. Tohoru and T. Yoshiki(1997). Production and properties of a lipopeptide biosurfactant from $B$. subtilis C9. J Ferment Bioeng 84: 41-46. 
Kloepper, J. W. and C. M. Ryu (2006). Bacterial endophytes as elicitors of induced systemic resistance. In: Microbial root endophytes, Heildelberg, (Schulz, B., C. Boyle and T. Siebern eds.), Springer, Verlag, 33-51 pp.

Lahlali, R., G. Peng; B. D. Gossen; L. McGregor; F. Q. Yu;R. K. Hynes; S. F. Hwang; M. R. McDonald and S. M. Boyetchko (2013). Evidence that the Biofungicide Serenade (Bacillus subtilis) Suppresses Clubroot on Canola via Antibiosis and Induced Host Resistance. Biol. Cont. 103: 245-254.

Lamberti ,F.(1981).Plant nematode problems in Mediterranean region helminthological Abstracts 50:145-166.

Li, L., Mo, M.H., Qu, Q., Luo, H., and Zhang, K.Q. (2007). Compounds inhibitory to nematophagous fungi produced by Bacillus sp. strain $\mathrm{H} 6$ isolated from fungistatic

Mai, W.F. and H.H. Lyon (1975). Pictorial Key to genera of plant parasitic nematodes. Fourth edition, revised. Ithaca, lonson: Comstock Publishing Associates, cernel Univ. Press, 219 PP.

Mannanov, R. and R. Sattarova (2009). Inhibition of cotton pathogens by natural antagonists. IOBC/WPRS Bulletin, 43: 255-258.

Norton, D.C. (1978).Ecology of plant parasitic nematode. John Willey and sons, New York, USA. 238 pp.

Oka, Y.,H. Koltai, M. Bar-Eyal, M. Mor, E.C. Sharon and I. Y. Spiegel ( 2000). New strategies for the control of plant parasitic nematodes. Pest Management Science., 56:983-988.

Podile, A.R. and G.K. Kishore (2002). Biological control of peanut diseases. In Biological control of crop disease edited by Samuel $S$. Gnamanickam.CRC.

Rahman Khan, M.;Shahana, M. Khan and Faya, Mohide (2005). Root-knot nematode problem ofsome winter ornamental plants and its biomanagement. Journal of Nematology, 37: 198-206.

Robinson, L., M. J. Jeger and P. Xiangming (2009). Management of strawberry gray mould using mixtures of biocontrol agents with different mechanisms of action. Biocontrol Science and Technology, 19: 1051-1065.

Sasser, J.N. and D. W.Freckman (1987).A World Perspective on Nematology: The Role of the Society. In: Vistas on Nematology, Veech, J.A. and D.W. Dickson (Eds.). Society of Nematologists, Hyattsville, Maryland, United States, pp: 7-14.

Sharma, P. and R. Pandey (2009). Biological control of root-knot nematode, Meloidogyne incognita in the medicinal plant, Withania somnifera and the effect of biocontrol agents on plant growth. Afr. J. Agric. Res., 4: 564-567.

Sharma,S.B. and D. McDonald (1990). Global status of nematode problems of groundnut, pigeonpea, chickpea, sorghum and pearl millet, and suggestions for future work. Crop protection ., 9:453-458

Sharon, E.; M. Bar-Eyal ; I. Chet; A. Herra-Estrella; O. Kleifeld and Y.Spiegel (2001). Biological control of the root-knot nematode, Meloidogyne javanica by Trichoderma harzianum.Phytopathology, 91:687-693. 
Siddiqi, M.R.(1986).Tylenchida, parasites of plants and insects. Slough, UK. Common W.Jnst. Parasite.645pp. soil. European Journal of Plant Pathology, Vol. 117, No. 4, pp. 329-340.

Steel, R.and G.D. Torrie (1980). Principles and procedures of statistics. $2^{\text {nd }}$ ed. McGraw-Hill, New York.

Taylor, A.L. and J.N. Sasser (1978).Biology, Identification and Control of Root-Knot Nematodes (Meloidogyne species). North Carolina State University, Raleigh, NC. USA. Pages: 111.

Tomaszewski, E.K.; M.A.M. Khalil; A.A. El-Deeb; T.O. Powers and J.L. Starr (1994). Meloidogyne javanica Parasitic on Peanut. J. Nematol., 26: 436-441.

Umesh Rud€rappa,copy right (2009-14) www.nutrition-and-you.com.Find us on Google+.

Westcott, S.W. and D.A. Kluepfe (1993).Inhibition of Criconemellaxenoplax egg hatch by Pseudomonas aureofaciens. Phytopathology. 83: 1245-1249.

Zhang, S. and X. Zhang (2009). Effects of two composted plant pesticide residues, incorporated with Trichoderma viride on root-knot nematode in balloon flower. J. Agric. Sci. China, 8: 447-454.

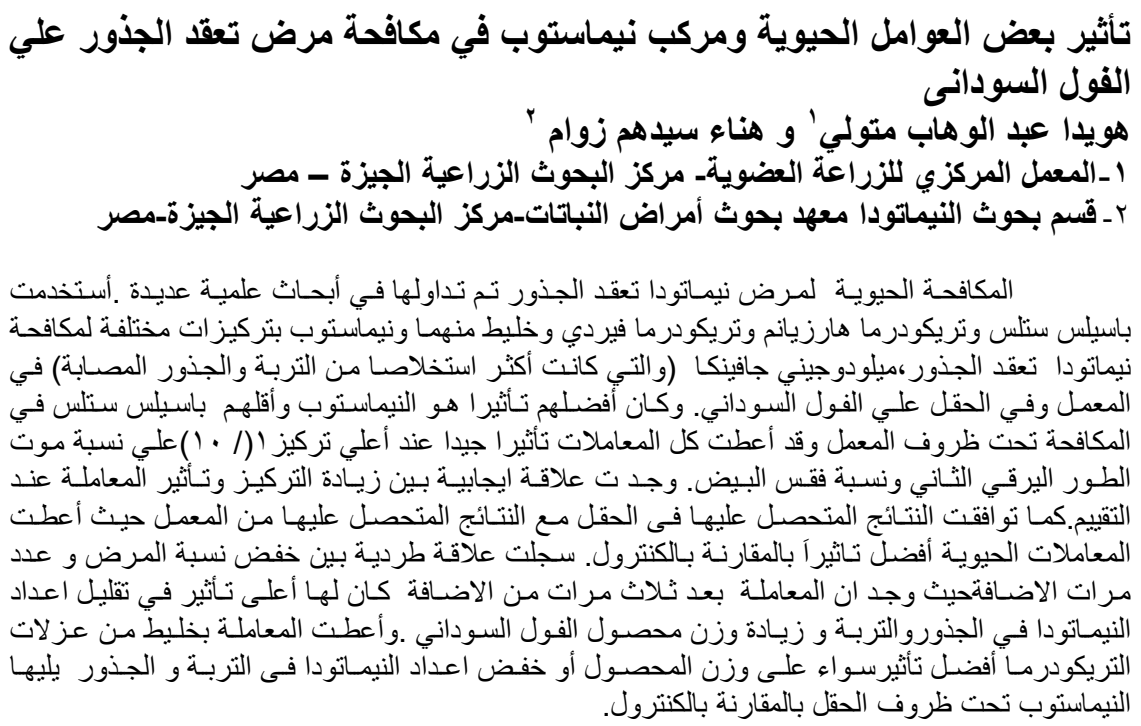




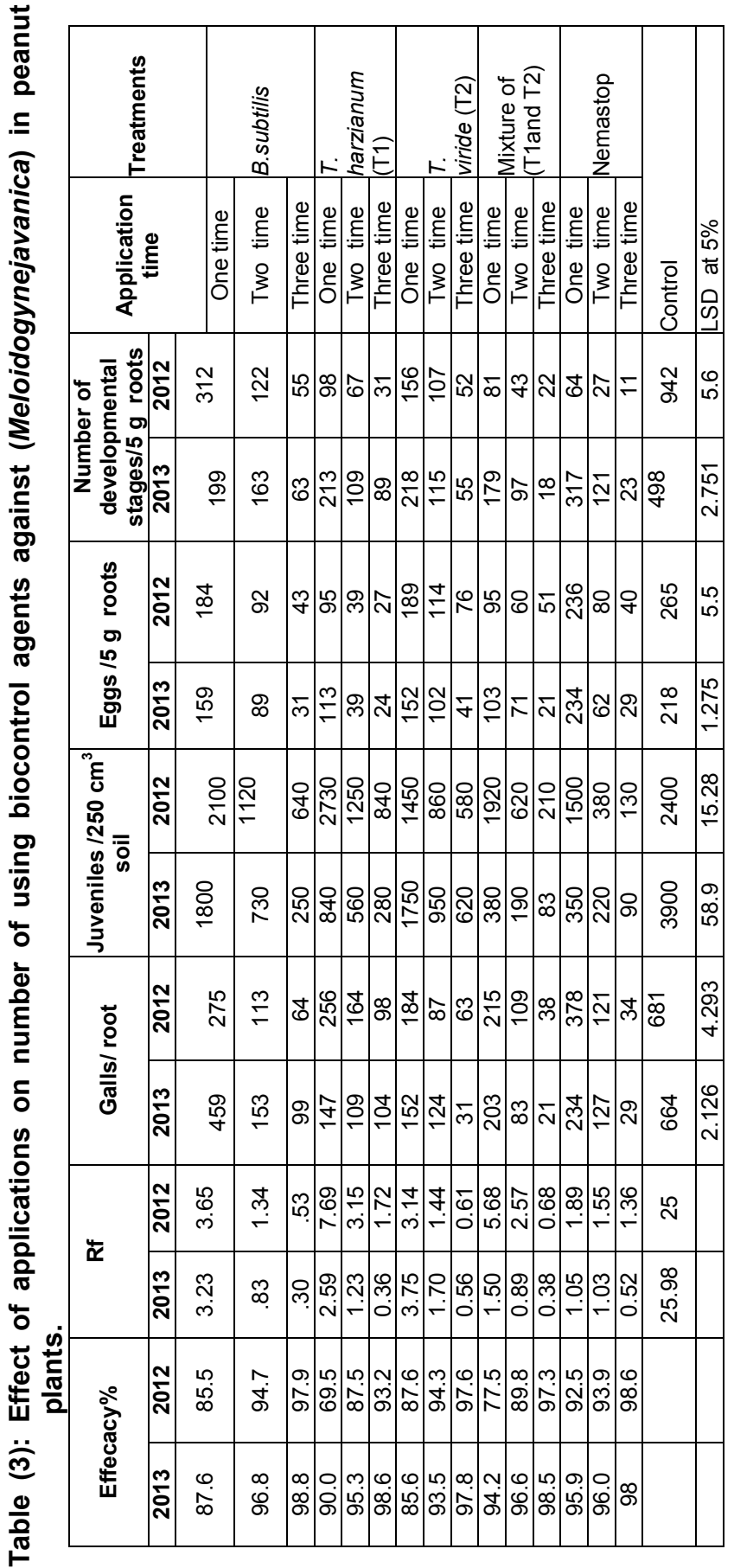

